\title{
THE CRUELTY OF DATA ABOUT SCIENTIFIC PUBLICATION PERFORMANCE: AN ASSESSMENT OF THE VISIBILITY OF HUNGARIAN SOCIAL SCIENCE BY ANALYZING HUNGARY'S MAIN REPOSITORY
}

\author{
PÉTER SASVÁRI ${ }^{1}$ ANDRÁS NEMESLAKI ${ }^{2}$
}

\begin{abstract}
The evaluation of scientific publication performance has become one of the most important and, at the same time, one of the most debated issues in international academic circles. This problem is attenuated by the digital transformation of science; online repositories, indexing systems and online visibility have become key enablers of evidence-based assessments of publication performance. In our paper we examine the scientific publication performance of 2131 members of the public body of the IX. Department of the Hungarian Academy of Sciences As its members represent the diversity of Hungarian social sciences very well, it was possible to make a broader generalization about their achievements regarding their publication performance. We found that one third of this sample has an internationally visible presence in the Repository of Hungarian Scientific Artefact (RHSA) database, which is the central repository that provides data for scientific promotion and assessment. By running a two-step cluster analysis we could identify five typical clusters of scientists based on their publications - each of them focusing on a different outlet such as books, domestic journals, international journals, or a balanced publication strategy that focuses on all the former types. In contrast to previous findings concerning technology acceptance, we found that the younger generation of Ph.Ds often adopt to the use of RHSA less than more senior individuals that have higher academic positions.
\end{abstract}

KEYWORDS: scientometrics, Hungarian Academy of Science, Scopus JEL: K00, M00

\footnotetext{
1 Péter Sasvári, Ph.D. is an associate professor at National University of Public Service, e-mail: sasvari.peter@uni-nke.hu

2 András Nemeslaki, C.Sc. is a professor at Budapest University of Technology and Economics, e-mail: nemeslaki@finance.bme.hu
} 


\section{INTRODUCTION}

Information communication technologies have disrupted and transformed numerous industries, especially since the commercial, mass-scale availability of internet. Manufacturing, communication, entertainment, and commerce are some of the classic examples which have changed in an almost unrecognizable fashion since the wide spread of ubiquitous ICT. Most recently education, healthcare, and public administration have been under the siege of technologybased transformation; accordingly, in our research we highlight what science - more specifically, the industry of scientific publications and the digital transformation challenge - means to scientists in a non-English-speaking Central Eastern European country.

As a result of digitalization, databases, online tools, open-access journals as illustrated in the case of Hungary - and local repositories make accessible a vast amount of data useful in analysis of actual publication performance. This situation elevates the importance of "evidence-based arguments" compared with "arguments of beliefs" about publication outputs. While Pajić (Pajić 2015) found that Eastern European countries largely base their international scientific production on the national journals covered by the Web of Science (WoS) and Scopus, we found that the performance of Hungarian management and social science followed a different strategy (Table 1).

Table 1 Hungary's performance in Scimago Journal and Country Rank (www.scimagojr.com) in the period 1996-2017.

\begin{tabular}{|c|c|c|c|c|}
\hline Subject Area & $\begin{array}{c}\text { Rank in Eastern Europe } \\
\text { (1996-2017) }\end{array}$ & H index & $\begin{array}{c}\text { Contribution } \\
\text { in 1996 }\end{array}$ & $\begin{array}{c}\text { Contribution } \\
\text { in 2017 }\end{array}$ \\
\hline Business & $9 / 24$ & 47 & $7.45 \%$ & $3.79 \%$ \\
\hline Economics & $7 / 24$ & 45 & $15.94 \%$ & $4.37 \%$ \\
\hline Social Sciences & $6 / 24$ & 84 & $10.37 \%$ & $5.81 \%$ \\
\hline Decision Sciences & $4 / 24$ & 49 & $11.9 \%$ & $5.98 \%$ \\
\hline
\end{tabular}

Source: Scimago Journal and Country Rank

What we see in Table 1 is that visibility of Hungarian social science in Scopus has dramatically decreased during the last 10 years or so, and this influences several areas of research, education, and institutional strategy.

We started our research based on the premise that discourses about publication visibility are too often subjective and neglect the examination of data. It happens quite often that individual research narratives, personal experiences, or different forms of scholastic chauvinism determine the perspective of arguments, and a comparison of the information or facts that can be extracted from available 
databases is often missing. For this reason, we undertook complex data analysis of several strands, one part of which that has not hitherto been carried out is presented in this study: namely, how the publication performance of the scientific community belonging to the IX. Department of the Hungarian Academy of Sciences (HAS) - the so-called Economics and Law Department (ELD) - can be structured. In essence, we asked the question what groups may be identified among the members of the public body in this department of HAS by analyzing their publication performance as stored in the Repository of Hungarian Scientific Artefacts (RHSA). With this in mind, we hoped to obtain deeper knowledge about the actual data concerning scientific performance, and by doing so, contribute to the evidence-based arguments involved in this debate.

\section{CONCEPTUAL BACKGROUND AND REVIEW OF LITERATURE}

There are numerous theories and concepts as to what determines international publication outputs. In the context of Central and Eastern European (CEE) countries, economic development (Vinkler 2008), the post-communist past (Kornai 1992) and being on the periphery of social sciences (Demeter 2018) are most often noted. This last issue has been recurringly presented in the literature as a major challenge for authors as individuals (Schmoch - Schubert 2008), institutions as competing scientific entities (Gumpenberger et al. 2016), and also for regions that have the intention of disseminating or acquiring knowledge in particular fields (Wang - Wang 2017). Stakeholder interest and objectives are also key factors in publication outputs (Shenhav 1986). In the case of social sciences, a lot of emphasis is placed on local relevance because this concept drives access to $R \& D$ resources (Bastow et al. 2014). On the other hand, relevant local problems do not often fall within mainstream areas of research discourse (Lauf 2005; Wiedemann - Meyen 2016). This situation results in an imbalanced flow of knowledge dissemination and absorption (Gerke - Evers 2006). We argue that all these issues are attenuated by the impact of information technology innovation - most importantly, the ubiquity of online networks and digitalization (Sasvári et al. 2019).

Digital disruption in the form of readily available repositories, online aggregators, indexing systems, and research platforms has created a major challenge for publication visibility (Nederhof 2006; Teodorescu - Andrei 2011; Bunz 2006). Apart from audited and centrally controlled main academic databases such as Elsevier's SCOPUS, which contains more than 30,000 journal 
titles, or Clarivate Analytics WoS, which contains 12,000 academic journals, there are also crowdsourcing and community-controlled visibility tools such as Researchgate, Academia.edu, and other initiatives such as Harzing's Publish or Perish and Google Scholar for increasing publication outreach and visibility (Delgado - Repiso 2013). Needless to say, numerous ethical questions come into play pertaining to academic standards, search bias, scoring algorithms, language preferences, and predatory business models that take advantage of the publication pressure placed on authors and institutions (Astaneh - Masoumi 2018). Irrespective of what kind of resistance there is to accepting new methods of publication dissemination and marketing techniques, one thing is very certain: as the digital ecosystem evolves in science, all stakeholders must assess the situation based on data and evidence from reliable and "accredited" sources (Demeter 2017a).

Countries might choose to use international repositories and indexing sites; they can also build their own local ones that cater to the publication policy and assessment needs of their local communities. Hungary chose the latter method; the idea was to establish a comprehensive database for collecting the scientific output of Hungarian researchers. Hungary's accredited and central publication repository is the Repository of Hungarian Scientific Artefacts (RHSA: www. mtmt.hu). This repository development project was initiated in 2008 by HAS, the Hungarian Accreditation Committee, The Rectors' Conference, the Council of Hungarian Doctoral Schools, and the National Foundation for Scientific Research (Makara - Seres 2013). These five founding organizations agreed that the repository needed to be a credible, auditable, and authentic source of Hungarian research artifacts, including domestic and international journal articles, books, patents, conference proceedings, educational materials, and other such items. Over the years, the RHSA system has been strengthened institutionally by several legislative acts; its maintenance and operations have been delegated to HAS. A dedicated governance body has been established consisting of library and research experts who develop its strategy and regularly report to the president and the general council of HAS (HAS Doctor of Science Requirements - www.mta.hu, 2018). There are links and migration tools to connect RHSA with Elsevier's SCOPUS and Clarivate Analytics' Web of Science repositories as well. Regardless of this integration, RHSA and its governance have practically developed their own evaluation system which has been the source of heated debate amongst Hungarian scientists (Csaba et al. 2014; Braun 2010). It is interesting to juxtapose RHSA-related academic arguments with the theoretical dilemmas of "core and periphery" (Demeter 2017b), indicating that a lack of attention is paid to periphery countries in the social sciences (Demeter 2018), resulting in the socalled Matthew Effect of scientific citations (Bonitz et al. 1997). 
Finally, as we have observed, the heat of the debate about which publication outlet is more important or creates more scientific value in a given environment, revolves around the concept of fairness. Fairness in this context means an unbiased judgement of the stature of scientific journals that enables an impartial evaluation of research performance in a particular field of science, as well as a comparison of new results and the added value of individual fields of science to one another (Templeton - Lewis 2015). In Hungary, fairness regarding social sciences is surrounded by suspicion originating from a number of individual researchers and also often from the evaluating institutions. Such resentment often results in institutional and scientific "chauvinism" in an attempt to protect fairness as a social construction of science (Soós - Schubert 2014).

The contribution of our research, based on these concepts, seeks to enhance the discourse on fairness by providing resources for high-level academic arguments concerning the Hungarian situation, and a case study for the international community which generates many general conclusions for periphery countries similar to Hungary. To achieve the first goal, we simply document a systematic exploratory data analysis of RHSA and reveal what the data say about the actual visibility of Hungarian social scientists. To accomplish the second goal, we connect results about the Hungarian case to these reviewed concepts and indicate the transferability of these ideas to other environments.

\section{CASE STUDY BACKGROUND}

In terms of academic scientific degrees, Hungary has three levels. The Ph.D. is the first level, basically originating from the classic western-university-based academic traditions - doctoral schools in different disciplines award doctoral degrees based a rigorous assessment process culminating in the defence of a thesis. Historically, at the first level numerous scientists possessed a so-called Candidate of Science degree (C.Sc.) which was awarded by the Hungarian Academy of Sciences based on a Soviet model involving the centralized quality control of research performance. This type of assessment has ceased to exist, but several hundred Hungarian scholars still hold this degree which is legally equivalent to a Ph.D. title.

The second level is also a Soviet-system-based academic degree provide by HAS, called Doctor of Science (D.Sc.) In order to obtain this title, one needs to possess a $\mathrm{Ph}$.D. or C.Sc. degree and has to demonstrate outstanding domestic and international academic performance in terms of publication, scholarship, and scientific leadership (Ph.D. supervision, leading research projects, etc.). Requirement for the D.Sc. vary between different scientific departments in HAS; for instance, in the III. Department 
of Mathematics it is mainly international publications that are assessed, in contrast to the II. Department of Philosophy and History where a monograph - basically a thesis - also needs to be submitted. Increasing the number of D.Sc. holders is a pivotal goal for all research-oriented universities in Hungary because doctoral schools can only be headed by the former.

After obtaining a D.Sc. degree, scientists might be elected as members of the Hungarian Academy of Sciences - initially as corresponding members, then regular ones, although the two categories do not differ in scientific rank. Promotion to this third level represents the peak of a research career in professional life. In 2017, members numbered 293. The limit for regular and correspondent HAS members younger than 70 years of age is 200 scholars, while the total number of HAS members is limited to 365 .

For the publication performance assessment of the above-described three categories in the Hungarian academic committee, we have chosen a sample registered in the largest public body of HAS. According to Act XL of 1994, the Academy's public tasks include the establishment of scientific departments, which are the basic units of scientific professional autonomy, and other related bodies (scientific committees, regional committees, etc.) as defined in the statutes. Our main reason for doing this is that membership in these public bodies is available to all Hungarian individuals who represent Hungarian scientific life, whether living in Hungary or abroad, who submit a written application for admittance, undertake the duties of being a member of the public body, and declare that they fulfill the requirements of membership as defined by law. During the period of research there was no real screening procedure involved in admission; the sole condition being possession of a Ph.D. or equivalent degree (Tolnai et al. 2009). Membership, accordingly, takes effect by registration.

Public bodies in HAS follow the structure of scientific departments, which are basically sections of the Academy that include representatives of disciplines considered to be related or close to each other by HAS members. These departments are the following, according to HAS Statutes and Regulations: Linguistics and Literary Scholarship, Philosophy and Historical Sciences, Mathematics, Agricultural Science, Medical Sciences, Engineering Sciences, Chemical Sciences, Biological Sciences, Economics and Law, Earth Sciences, and Physical Sciences. In 2017, the total number of living public body members was 15,707 individuals, of whom the largest proportion were registered to the Economics and Law Department, and the least to the Mathematics Department (2,131 and 732, respectively). As far as academic ranking is concerned, ELD has the least HAS members (55) compared to other departments, while the greatest number can be found in the Mathematics Department (81). In contrast, ELD accounts for the greatest number of PhDs: 1,092 from the total of 7,741. 
The ELD of HAS was originally established for and by academics working in economics and law. Later, different scientific areas and disciplines were added to this department. Presently, the scientific and doctoral committees of this department grant "Doctor of Sciences" (D.Sc.) degrees in the following disciplines (HAS Doctor of Science Requirements - www.mta.hu, 2018):

- Business and Management Studies (BUS),

- Demographic and Labor Studies (DEM),

- Economics (ECO),

- Legal and Governmental Sciences (LAW),

- Military Science (MIL),

- Political Science (POL),

- Regional Studies (REG),

- Sociology (SOC),

- Statistics and Future Studies Research (FUT),

- World Economics and Development Studies (WED).

These committees play a pivotal role in setting scientific standards for doctoral education, establishing guidelines for academic promotion, and laying down principles for scientific practice, both at research institutes and at universities. Doctoral schools that award Ph.D. degrees can only be directed by academics who possess D.Sc. Degrees, thus the role of the HAS is not only theoretical, but also institutional.

\section{SOURCE OF DATA}

In order to analyze publication performance, we collected two sources of data about the 2131 listed public members of the ten committees in ELD at HAS as of June 2017.

First, we used the database of the National Doctoral Council (available at NDC: www.doktori.hu) which mainly contains demographic information and details of scientific rank with positions. Since it is not typical that members of the public bodies make their date of birth public, we could only identify 1872 of the latter on the pages of NDC and other sources (Tolnai et al. 2009). Amongst the public members of the ELD committees, we identified 55 HAS members, 225 Doctors of Science (D.Sc.), 758 Candidates of Science (C.Sc.), and $1092 \mathrm{Ph} . \mathrm{D}$. degree holders. Their average ages were 76, 70, 70, and 48 (respectively) in 2017. Figure 1 illustrates the demographic data in our sample. 
Figure 1 Distribution of members of the public body in the IX. Economics and Law Department by age and scientific degree.

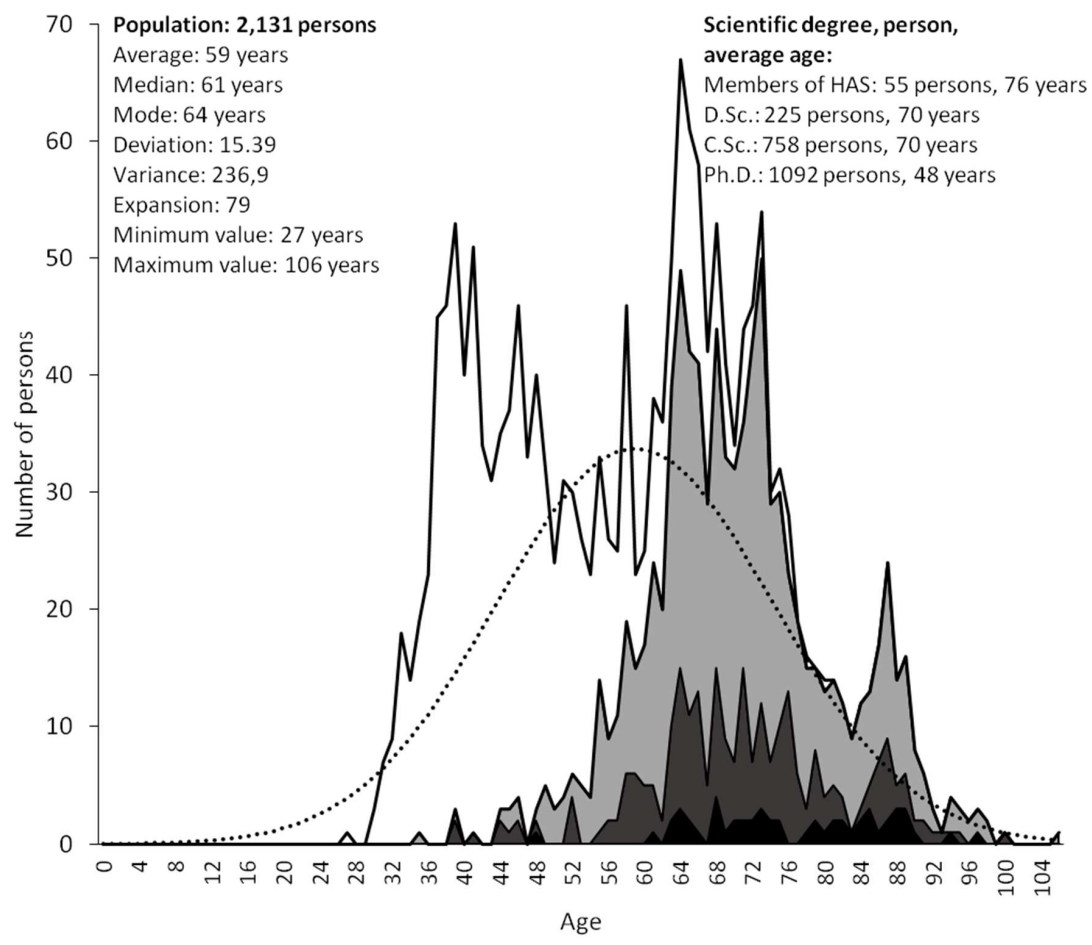

Members of HAS

D.Sc.

C.Sc.

$\square \mathrm{Ph} . \mathrm{D}$. Normal distribution

Second, we collected publicly available publication data from the Repository of Hungarian Scientific Artefacts (RHSA: www.mtmt.hu), as introduced earlier. The structure of our data is presented in Table 2, showing the four main groups of collected data: a) researcher identifiers, b) researchers' prestige data set, c) standard RHSA data, and d) researchers' citations in RHSA and in SCOPUS. 
Table 2 Data collected about 2131 Public Body Members in ELD of HAS

\begin{tabular}{|c|c|c|}
\hline \multicolumn{3}{|c|}{ Researcher Identifiers } \\
\hline Name & & Text \\
\hline Scientific field & & Text \\
\hline RHSA identifier & & Numerical Code \\
\hline Date of birth & & Numerical \\
\hline Academic qualification & Ph.D., C.Sc., D.Sc., Acad. & Category variable \\
\hline Academic sub-committee membership & see separate section & Category variable \\
\hline \multicolumn{3}{|c|}{ Prestige Data Set } \\
\hline SCOPUS Publications 2012-17 & Q1 (D1), Q2, Q3, Q4 & Numerical \\
\hline Not Rated in Scopus 2012-17 & & Numerical \\
\hline HAS Listed Papers 2012-17 & $\mathrm{A}, \mathrm{B}, \mathrm{C}, \mathrm{D}$ & Numerical \\
\hline Not Rated Papers in HAS 2012-17 & & Numerical \\
\hline SCOPUS Publications 1999-17 & Q1 (D1), Q2, Q3, Q4 & Numerical \\
\hline Not Rated in Scopus 1999-17 & & Numerical \\
\hline HAS Listed Papers 1999-17 & $\mathrm{A}, \mathrm{B}, \mathrm{C}, \mathrm{D}$ & Numerical \\
\hline Not Rated Papers in HAS 1999-17 & & Numerical \\
\hline \multicolumn{3}{|c|}{ Standard RHSA data } \\
\hline Scientific Peer Reviewed Papers & \multirow{15}{*}{$\begin{array}{l}\text { Scientific publications in } \\
\text { verified } \\
\text { sources according to RHSA } \\
\text { regulations. }\end{array}$} & Numerical \\
\hline Peer Reviewed International foreign & & Numerical \\
\hline Peer Reviewed International domestic & & Numerical \\
\hline Peer Reviewed Hungarian & & Numerical \\
\hline Books & & Numerical \\
\hline Author in Hungarian & & Numerical \\
\hline Author in Foreign Language & & Numerical \\
\hline Editor in Hungarian & & Numerical \\
\hline Editor in Foreign Language & & Numerical \\
\hline Book Chapter & & Numerical \\
\hline Book Chapter in Hungarian & & Numerical \\
\hline Book Chapter in Foreign Language & & Numerical \\
\hline Conference Proceedings & & Numerical \\
\hline Proceedings in Hungarian & & Numerical \\
\hline Proceedings in Foreign Language & & Numerical \\
\hline $\begin{array}{l}\text { Scientific publications in non-verified } \\
\text { sources }\end{array}$ & $\begin{array}{l}\text { According to RHSA } \\
\text { regulations. }\end{array}$ & Numerical \\
\hline Educational Materials (texts, cases, notes) & & Numerical \\
\hline General publications for dissemination & & Numerical \\
\hline \multicolumn{3}{|c|}{ Science Metrics for Researchers } \\
\hline Total number of recorded citations & From RHSA & Numerical \\
\hline H-index calculated in RHSA database & From RHSA & Numerical \\
\hline H-index in SCOPUS & From Scopus & Numerical \\
\hline
\end{tabular}


As we can see, standard RHSA practice involves organizing publications into five categories, as follows: a) Scientific Publications in Verified Sources, b) Scientific publications in Non-Verified sources according to RHSA regulations, c) Textbooks, cases and other educational materials, d) Patents and registered innovations, e) General publications for information dissemination and public awareness. Scientific Peer-reviewed Publications are then further divided into Hungarian and international groups in the following areas: a) journal articles, b) edited and authored books, c) book chapters, and e) conference proceedings.

Since 2012, regular RHSA data collection has been amended by so-called "Prestige data sets." Prestige data is filtered information from RHSA according to two sets of criteria: a) according to the quartile-based classification of Scimago (González-Pereira et al., 2010) based on the SCOPUS database (Q1-Q4), and b) according to the quartile-based classification of the sub-committees of HAS's department of Economics and Legal Science (A-D). Namely, sub-committees categorize Hungarian and non-Hungarian journals into four categories (' $A$ ' the highest and ' $\mathrm{D}$ ' the lowest) according to their scientific value as assessed by the particular committee. Prestige data sets are not only considered the highest value academic output, but moreover show how up-to-date researchers' publication activity is by always aggregating the last five years of published research.

From RHSA we collected all the above data to analyze the academic visibility of 2,131 researchers who are registered public body members of HAS's Economic and Legal Science Department. We used SPSS Statistics for Windows (IBM Corp. Armonk, NY, Version 24.0. 2016) and Excel (Microsoft, Redmond, WA, Version 2016) modeling to test our three propositions.

\section{DISCUSSION OF RESULTS}

\section{Completeness of data in RHSA: visibility of publication output in the IX. Department of HAS}

The number of scientific publications of members of public bodies in the IX. Department of HAS was nearly 147,000 at the beginning of 2017, of which there were 44,000 scientific journal articles, 16,000 books, 32,000 book chapters, 17,000 conference proceedings, and 38,000 non-scientific works. Of the latter, higher education textbooks amounted to nearly 6,000, and the number of educational materials to 3,800 .

For all publication types, numbers increase by academic position, as one would expect. For instance, the average number of scientific papers was 97 by HAS 
members, 62 by D.Scs, 29 by C.Scs, and 21 by Ph.Ds throughout their career. Similarly, Ph.D. degree holders have published 7 books on average, C.Scs 12, D.Ses 25 , and HAS members 33 books per person. Data show similar tendencies in the case of book chapters and conference proceedings. It is interesting to register that the total number of items in the scientific publication category by individuals in RHSA is 62 on average, and 53, 73, 142, and 204 in ascending order of Ph.D., C.Sc., D.Sc. and HAS members, respectively.

Committees in the ELD of HAS show differences in terms of RHSA data. Most scientific papers were written by members of WED (45 per person), and the least by the members of ECO ( 21 per person). Within the category of international journals, WED ranks highest with 7 papers per person, and MIL the lowest with 1 piece per person. Most articles in Hungarian-language journals were also published by WED members (34 articles per person) and the least by ECO (13 articles per person). Most books are published in WED (16 per person), most book chapters in POL and LAW (32-32 per person) and most conference proceedings come from ECO (23 per person). Low figures for conference proceedings can be found for SOC (4 per person), and for both book chapters and books in BUS (7 and 6 per person, respectively).

Figure 2 Mechanisms (levels) of lack of on-line visibility - 32\% of ELD public member scholars have regular, internationally visible publication entries in RHSA

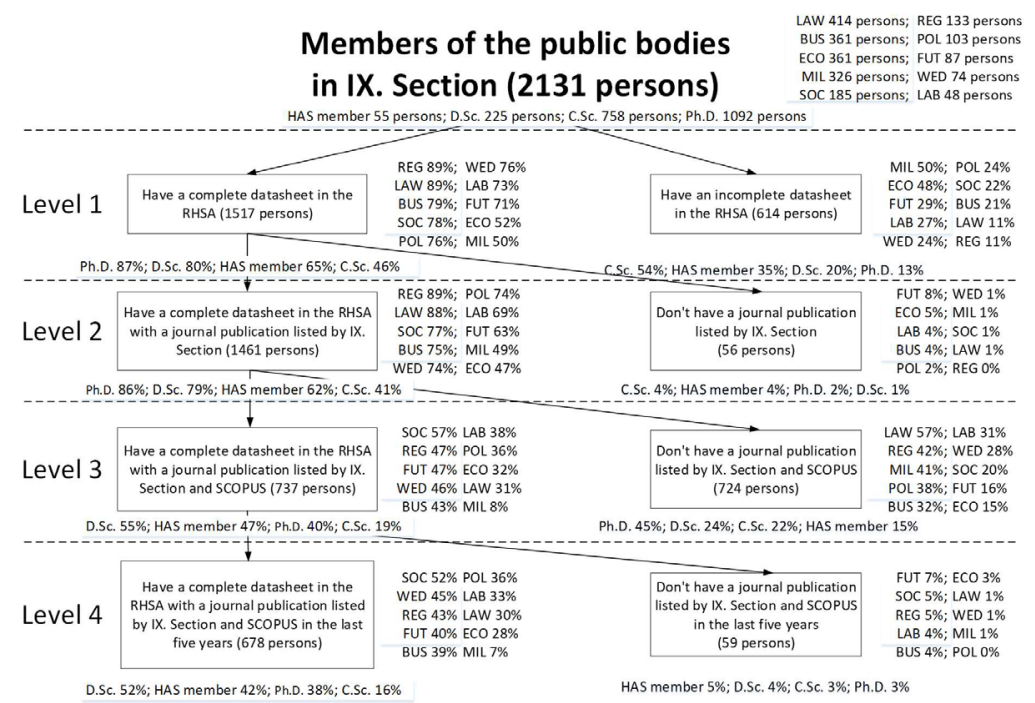


In order to further explore RHSA and draw deeper conclusions about publication performances by committee and academic position, we need to assess the completeness of RHSA in connection with how seriously public members take the maintenance of their account at RHSA, and how strong their online visibility is. Figure 2 includes four main mechanisms showing how access is lost to publication data, and how scholars become invisible on-line.

Twenty-nine percent of our sample (613 individuals) are invisible in RHSA or have an incomplete presence in the repository. They either have no identifier, no summary table of scientific publications, or no prestige table indicating ranked international or domestic publications. As far as academic position is concerned, 19 of the former are members of HAS, 45 are D.Scs, 412 are C.Scs and 137 are $\mathrm{Ph}$.D. holders. Given the fact that the average age of the non-visible group (72 years) is 13 years more than the age of other members of the sample, it seems to logical to assume that those researchers who are not engaged with the digital transformation are those whose careers are not impacted by the importance of on-line visibility. Since the publication performance required for Ph.D. degrees, D.Sc. positions, and HAS membership is only assessed based on RHSA data, we might conclude that the 613 non-visible researchers are either not interested in pursuing academic qualifications, obtained their positions before the online repositories were established, or - and this the most alarming conclusion - do not publish in outlets with any visibility. Looking at this issue according to the data for different committees shows that half of MIL members, nearly half of BUS, one-third of WED, and more than a quarter of DEM members do not have a complete data sheet in RHSA. In our model of digital visibility completeness, we have labeled this lack as Level 1.

For Level 2 we divided the 1518 public institution members who have a valid and visible account in the RHSA into two further groups. We excluded 56 individuals from further analysis since their data records did not indicate any journal publications in HAS-listed domestic or international journals. As Figure 2 shows, the proportion of these researchers compared both to academic positions and to discipline-based committees in ELD is small (3\% of all public institution members) and in many cases is very likely the result of data input error. The second group at Level 2 contains 1,461 public institution members in the IX. Department of HAS who have at least one publication in a HAS-listed journal. This accounts for $62 \%$ of HAS members (34 persons), $79 \%$ of D.Sc.(177 persons), $41 \%$ of C.Sc.- (314 persons) and $86 \%$ of Ph.D. degree holders (936 persons). The average age of this group is 54 years, which is five years less than the average age of the public institution members of IX. Department.

As far as committees are concerned, at Level 2 most researchers who have HAS journal publications are in REG (89\%) and LAB (88\%), while the least are 
affiliated with MIL (49\%) and BUS (47\%). As a result of RHSA data at Level 2 , we conclude that $68.5 \%$ of our sample - slightly more than two-thirds of registered public institution members - have published in journal(s), while the rest have not taken HAS listings into consideration or have only published in books or conference proceedings.

At Level 3 we found that those who have journal publications may be almost equally dived into a group that publishes only in domestic, Hungarian journals (724), and into another group whose members have at least one paper in a Scopus-indexed - internationally ranked - journal (737). In this group, 230 individuals only have one publication, which of course raises the question if they can be considered "internationally published researchers."

Among the 724 persons who belong to the first group there are 8 members of HAS, 53 D.Scs, 169 C.Scs, and 494 Ph.Ds. Their average age is 55 years, which is only a year older than the 737 who have published at least one scientific article in a SCOPUS-ranked journal. It is important to note that some of these researchers have published in international journals, although they are not SCOPUS listed ones; RHSA data show that this group published 1,065 international journal articles issued in Hungary, and 1,274 published in foreign countries. Regardless, our Level 3 analysis identifies that $34.5 \%$ of our sample - slightly more than one-third of enlisted public body members - can be considered scholars who publish in SCOPUS-indexed journals, which represents one means of ensuring quality digital visibility.

Finally, we excluded another 59 public body members from our detailed clustering because their journal publication activities - both HAS-listed and SCOPUS - did not show any entries for between 2012-2017, which is called the "last-five-years" category. We considered this fact to be an important indicator of recent publication-related endeavors, or the lack of them. Level 4 analysis reveals that the share of public body members who had published articles in quality international journals in the "2012-2017" category and had a complete data sheet in RHSA is $32 \%$ of the total sample (678 persons).

All in all, the completeness of the RHSA - as the main official data source - shows that less than one-third of the public body members of the IX. Department of HAS have a broad enough publication depth and breath to draw evidence-based conclusions. In our opinion, this is a key indication of serious problems with adopting to the digital transformation of science in the area of economics, business, sociology, law and other related disciplines. Although our sample naturally does not include a lot of scholars from these fields, public body members are considered a leading group of academics - all have at least a Ph.D. - so we argue that our data proves the existence of a serious adoption and publication performance problem. Breaking this data down into academic 
positions, only $42 \%$ of HAS members, $52 \%$ of D.Sc-, $16 \%$ of C.Sc.- and $38 \%$ of Ph.D. holders keep their RHSA accounts up-to-date. Scientific committees are different from this perspective: sociology contains the largest $(\mathrm{SOC}=52 \%)$ and military science the smallest $(\mathrm{MIL}=7 \%$ ) proportion of public body membership with a regularly maintained RHSA account.

Table 3 Number and proportion of scholars publishing in Hungarian and international journals listed (not listed) by Scopus according to scientific degree

\begin{tabular}{|c|c|c|c|c|}
\hline & \multicolumn{2}{|c|}{$\begin{array}{c}\text { Number and proportion } \\
\text { of scholars publishing in } \\
\text { NON-SCOPUS journals }\end{array}$} & \multicolumn{2}{|c|}{$\begin{array}{c}\text { Number and proportion } \\
\text { of scholars publishing in } \\
\text { SCOPUS journals. }\end{array}$} \\
\hline Unit of measure & persons & percent & persons & percent \\
\hline Members of HAS & 8 & $24 \%$ & 26 & $76 \%$ \\
\hline D.Sc. & 53 & $30 \%$ & 124 & $70 \%$ \\
\hline C.Sc. & 169 & $54 \%$ & 145 & $46 \%$ \\
\hline Ph.D. & 494 & $53 \%$ & 441 & $47 \%$ \\
\hline Total & 724 & & 736 & \\
\hline
\end{tabular}

Source: RHSA

It can be verified with a simple Chi-squared test that the difference between scholars whose visibility originates from Non-Scopus and Scopus journals is not random. Furthermore, as Table 3 shows, the results contradict the common "acceptance-of-technology" notion that the younger generation adopts to the use of digital technology better than the older one; according to HAS promotion regulations, members and D.Sc. holders are significantly more published in Scopus than the younger C.Scs or Ph.Ds. This finding draws attention to Ph.D. requirements, which in most doctoral schools do not prescribe that candidates publish in Scopus or other internationally indexed journals (e.g. Clarivate's Web of Science).

In the next part of our analysis (Level 5), we examine the 678 public body members' RHSA accounts in order to seek out publication patterns which provide further insight into behavior and performance in ELD.

\section{Cluster Analysis of internationally visible researchers in ELD at HAS}

In order to identify natural groupings for our regularly published and internationally visible 618 researchers, we used the exploratory two-step cluster analysis of the statistical software package SPSS, as shown in Figure 3. 
Figure 3 Scientific performance of internationally visible members in ELD public bodies

\section{Level 5}

\begin{tabular}{l}
\hline $\begin{array}{c}\text { Conference } \\
\text { participants } \\
\text { (55 persons) }\end{array}$ \\
BUS $9.1 \%$; MIL $0.3 \%$ \\
REG $7.5 \%$; LAB $0.0 \%$ \\
FUT $4.6 \%$; WED $0.0 \%$ \\
ECO $1.1 \%$; POL $0.0 \%$ \\
LAW $0.5 \%$; SOC $0.0 \%$ \\
HAS member $7.3 \%$ \\
D.SC. $3.1 \%$ \\
Ph.D. $2.5 \%$ \\
C.SC. $2.2 \%$
\end{tabular}

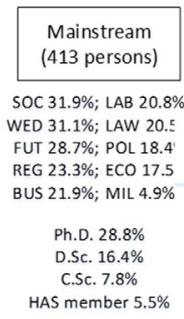

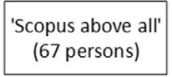

SOC $6.5 \%$; WED $2.7 \%$ POL $4.9 \%$; FUT $2.3 \%$ REG $4.5 \%$; LAW $1.2 \%$ ECO $4.4 \%$; MIL $0.9 \%$ BUS $3.6 \%$; LAB $0.0 \%$

$$
\begin{gathered}
\text { D.Sc. } 7,6 \% \\
\text { HAS member } 7,3 \% \\
\text { Ph.D. } 3,1 \% \\
\text { C.Sc. } 1,6 \%
\end{gathered}
$$

\begin{tabular}{|c|}
\hline $\begin{array}{c}\text { Super Team } \\
\text { (10 persons) }\end{array}$ \\
\hline FUT $1.1 \%$; REG $0.0 \%$ \\
POL $1.0 \%$; MIL $0.0 \%$ \\
ECO 0.8\%; LAB 0.0\% \\
LAW 0.5\%; WED 0.0\% \\
BUS 0.3\%; SOC $0.0 \%$ \\
HAS member $5.5 \%$ \\
D.Sc. $1.8 \%$ \\
Ph.D. $0.2 \%$ \\
C.Sc. $0.1 \%$
\end{tabular}

Source: RHSA

The procedure for two-step cluster analysis uses log-likelihood distance measures which assume a normal distribution for continuous variables. Although our four input variables (conference proceedings, papers indexed in SCOPUS, books and scientific publications in non-verified sources), as shown in Table 5, do not meet the normality assumptions, with reference to the robustness of the method, and building upon our large sample size $(618>200)$, we assessed that a two-step clustering method was still applicable (Bacher et al., 2004). This was further confirmed by the non-parametric independence tests of the input variables where Kendall's tau was less than 0.4 in all significant cases $(p<0.05)$, and, although correlations should ideally not exist, we went ahead with our method partly because the correlation measures were low, and because with all four variables the variance was significantly higher than the mean value, therefore strong and significant correlations could not be inferred (Bacher et al., 2004), (Trpkova - Tevdovski, 2010).

For the determination of cluster numbers we used Euclidean distance and Akaike Information Criteria (AIC). The analysis resulted in five clusters, as described in Table 3, which we accepted based on the computed silhouette measure of 0.5 . Silhouette measures vary between -1 and +1 and describe the cohesion of cases within a cluster and their separation from other clusters. A result of 0.5 in our case is a "fair" cohesion and separation value. Acceptance of clusters was also reinforced by the relatively high values for predictor importance, which are usually omitted from the analysis if their value is less than 0.4 ; in our case the lowest was 0.56 so all four predictors made a significant contribution to grouping the cases into the cluster groups. 
Table 4 Result of Two-Step Cluster Analysis

\begin{tabular}{|c|c|c|c|c|c|c|}
\hline $\begin{array}{c}\text { Cluster } \\
\text { Averages }\end{array}$ & $\begin{array}{c}\text { Predictor } \\
\text { Importance }\end{array}$ & $\begin{array}{c}\text { SPSS } \\
\text { Code }\end{array}$ & $\begin{array}{c}\text { SPSS } \\
\text { Code } \mathbf{1}\end{array}$ & $\begin{array}{c}\text { SPSS } \\
\text { Code5 }\end{array}$ & $\begin{array}{c}\text { SPSS } \\
\text { Code 3 }\end{array}$ & $\begin{array}{c}\text { SPSS } \\
\text { Code 4 }\end{array}$ \\
\hline Cluster Size & 678 & 10 & 55 & 67 & 133 & 413 \\
\hline CONFPROC & 1 & 21.6 & 64.56 & 12.81 & 12.18 & 8.01 \\
\hline SCOPUSALL & 0.84 & 31.2 & 4.07 & 16.64 & 4.08 & 2.84 \\
\hline BOOKSALL & 0.84 & 81.3 & 17.31 & 12.43 & 28.37 & 7.29 \\
\hline SCINONVER & 0.56 & 194.9 & 58.09 & 24.49 & 60.11 & 16.53 \\
\hline Name & & Champions & $\begin{array}{c}\text { Conference } \\
\text { attenders }\end{array}$ & $\begin{array}{c}\text { Scopus } \\
\text { visible }\end{array}$ & $\begin{array}{c}\text { Book } \\
\text { writers }\end{array}$ & Mainstream \\
\hline
\end{tabular}

Silhouette measure $=0.5$ Rated as Fair Clustering

Source: RHSA

Generally, the numbers in Table 4 are the mean values of the predictor variables in each cluster. We named the clusters according to the highest value types of publication.

The most populated cluster of researchers are located in SPSS_Code 4 (413 individuals) which we named the Mainstream group. As we can see in Table 4 , on average members have published more than eight conference proceedings, almost three SCOPUS indexed papers, more than seven books and sixteen scientific publications in non-verified sources on average.

In the second biggest cluster of SPSS_Code 3, the algorithm grouped 133 individuals. We call them Book Writers since they have published almost four times as many books and non-verified publications as the Mainstream group. Their SCOPUS and conference presence is also more dominant, with an average of 4.08 and 12.18 publications, respectively.

The SCOPUS-Visible group of researchers proves to be the third category (SPSS_Code 5 with 67 members). They have each published more than 16 SCOPUS or other indexed publications, which is four times more than the Mainstream and two times more than the Book Writers.

There are 55 members of the group Conference Attenders (SPSS_Code 1) who have mostly published in conference proceedings (64.56/person) and in non-verified sources (58.09/person). On average they have published over 17 books and have 4.07 Scopus publications.

Finally, we identified an elite small group of researchers (10 persons) in SPSS Code 2 who have an outstanding number of publication entries in RHSA (the highest in SCOPUS and the most books and non-verified source publications, while conference proceedings are the second highest). They are the Champions, and for the Hungarian research and publication community their identification and individual case histories might be pivotal for bench-marking and analysis. For an international audience, the particular individuals are not relevant, but 
more important are the conclusions we can draw by further analyzing the clusters.

In terms of age, the oldest subgroup is the Champions (63 years), the Book Writers (62 years), the Conference Attenders (57 years), SCOPUS Visible (53 years) while the youngest subgroup is the Mainstream (50 years). As far as academic degrees are concerned, the clusters look slightly but significantly different from each other (Pearson correlation $=0.196, \mathrm{p}<0.01$ ).

Table 5 Structure of clusters by Academic Degree

\begin{tabular}{|c|c|c|c|c|c|c|}
\hline \multirow{2}{*}{\multicolumn{2}{|c|}{ Two-Step Clusters }} & \multicolumn{4}{|c|}{ Academic Degree } & \multirow{3}{*}{\begin{tabular}{|c|} 
Total \\
55 \\
\end{tabular}} \\
\hline & & \multirow{2}{*}{$\begin{array}{c}\text { Ph.D. } \\
27\end{array}$} & \multirow{2}{*}{$\begin{array}{c}\text { C.Sc. } \\
17\end{array}$} & \multirow{2}{*}{$\begin{array}{c}\text { D.Sc. } \\
7\end{array}$} & \multirow{2}{*}{ 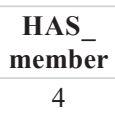 } & \\
\hline \multirow{3}{*}{$\begin{array}{l}\text { Conference } \\
\text { Attenders }\end{array}$} & Count & & & & & \\
\hline & Expected Count & 33.6 & 10.2 & 9.4 & 1.9 & 55,0 \\
\hline & $\%$ within Degree & $6.5 \%$ & $13.6 \%$ & $6.0 \%$ & $17.4 \%$ & $8,1 \%$ \\
\hline \multirow{3}{*}{ Champions } & Count & 2 & 1 & 4 & 3 & 10 \\
\hline & Expected Count & 6.1 & 1.8 & 1.7 & .3 & 10,0 \\
\hline & $\%$ within Degree & $0.5 \%$ & $0.8 \%$ & $3.4 \%$ & $13.0 \%$ & $1,5 \%$ \\
\hline \multirow{3}{*}{$\begin{array}{c}\text { Book } \\
\text { Writers }\end{array}$} & Count & 37 & 36 & 51 & 9 & 133 \\
\hline & Expected Count & 81.1 & 24.6 & 22.8 & 4.5 & 133,0 \\
\hline & $\%$ within Degree & $9.0 \%$ & $28.8 \%$ & $44.0 \%$ & $39.1 \%$ & $19,6 \%$ \\
\hline \multirow{3}{*}{ Mainstream } & Count & 313 & 59 & 37 & 3 & 412 \\
\hline & Expected Count & 251.3 & 76.1 & 70.6 & 14.0 & 412,0 \\
\hline & $\%$ within Degree & $75.8 \%$ & $47.2 \%$ & $31.9 \%$ & $13.0 \%$ & $60,9 \%$ \\
\hline \multirow{3}{*}{$\begin{array}{l}\text { Scopus } \\
\text { Visible }\end{array}$} & Count & 34 & 12 & 17 & 4 & 67 \\
\hline & Expected Count & 40.9 & 12.4 & 11.5 & 2.3 & 67,0 \\
\hline & $\%$ within Degree & $8.2 \%$ & $9.6 \%$ & $14.7 \%$ & $17.4 \%$ & $9,9 \%$ \\
\hline \multirow{3}{*}{ Total } & Count & 413 & 125 & 116 & 23 & 677 \\
\hline & Expected Count & 413,0 & 125.0 & 116.0 & 23.0 & 677.0 \\
\hline & \% within Degree & $100,0 \%$ & $100.0 \%$ & $100.0 \%$ & $100.0 \%$ & $100.0 \%$ \\
\hline
\end{tabular}

Source: RHSA

Table 5 shows that $76 \%$ of $\mathrm{PhD}$ degree holders belong to the Mainstream cluster, and as we go higher in the academic ranks, the proportion diminishes in this group - doctors of science and academic members belong here $32 \%$ and $13 \%$, respectively). With an international orientation - SCOPUS Visible - the situation is different: the higher the academic degree, the greater the publication performance, although even amongst academic members the proportion does not reach $18 \%$ from the 23 that were analyzed. This data pattern can be explained by promotion requirements, which define in each sub-committee international publication as a condition for the awarding of a doctor of science degree or 
HAS membership. Regardless, these conditions are specified for granting $\mathrm{PhD}$ degrees as well, and for any type of academic promotion; the proportion of the SCOPUS Visible group appears to be especially low if we compare its membership to the total number of public body members of HAS ELD (3\% Ph.D., 2\% C.Sc., 8\% D.Sc., 7\% HAS members).

The second most populated cluster, Book Writers, also shows an interesting pattern in terms of academic degrees. The proportion of $\mathrm{Ph}$.Ds in this group (9\%) almost equals that of the SCOPUS Visible group (8\%) and is higher than that of the Conference Attenders (6.5\%). This indicates that Ph.Ds seem to be more preoccupied by writing monographs, books, and book chapters than going to conferences and gaining exposure to international review. The largest proportion of this cluster are DSc degree holders, which finding is in alignment with most of the committee's requirements for awarding this degree of a published monograph.

Figure 4 Cluster visualization - publishing properties of researchers with Scopus-listed publications

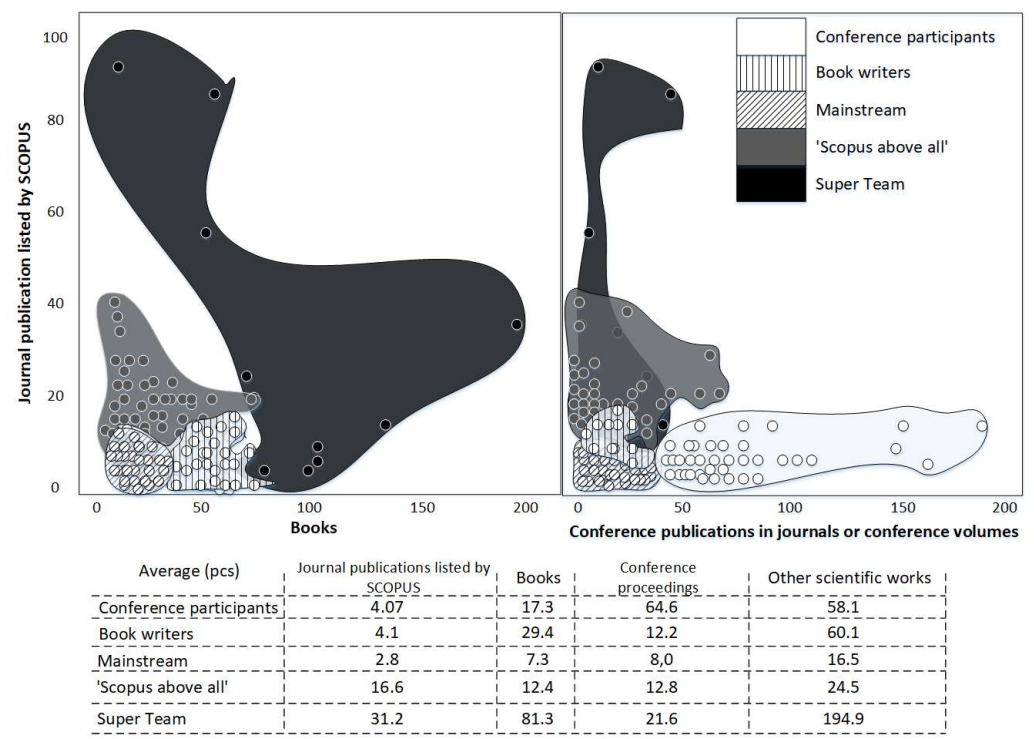

Source: RHSA

After running a cross-tabulation and correlation analysis of the clusters and committees we did not find significant correlation between clusters and academic 
committees either using parametric or non-parametric tests. We consider this an important exploratory finding for the performance assessment of HAS's EL Department, since, although there are major differences in the publication data between committees, we cannot reject the null hypothesis that this is just due to random effects. For instance, as we expected, the Mainstream cluster is the biggest in each of the committees, while Champions occur rather randomly in each. Furthermore, in most committees Book Writers are the second largest cluster, but it is important to note that in the cases of BUS, MIL and ECO this proportion is equal to or within $1 \%$ of the SCOPUS Visible cluster, showing the different publication culture in these committees.

In Figure 4 we illustrate the five clusters of scholars using dual coordination systems. The left chart in Figure 4 demonstrates the Champions (Super Group) and Scopus-above-all clusters, and the right chart emphasizes the Conference Attenders compared to the rest of the clusters.

\section{CONCLUSIONS}

In the current paper, we demonstrate how the performance of Hungarian social science can be structured based on the online visibility of public body members of the IX. Department (Economics and Law) of the Hungarian Academy of Sciences (HAS). At the beginning of 2017, fewer than a third of the 2,131 registered members, working in ten different committees (business, economics, sociology, political science, military science, law, world economics, labor studies, demography, and future studies), had a regularly maintained account in the RHSA containing broad enough records, including domestic and internationally indexed journal publications. Beyond this, our analysis has shown that while there is no significant difference between the ten committees of IX. Department, a non-random difference can be identified between the different academic positions, surprisingly showing less visibility or publication performance in the case of younger generations of Ph.Ds. It seems that Scopusindexed publications are relevant only to those scholars who want to pursue a promotional path dictated by HAS regulations which demand international visibility and a critical amount of citations.

In our opinion, the data demonstrate that the scientific visibility of the members of the IX. Department of HAS is low, and theoretical debates should take this evidence into account. Our data justifies that the problem basically involves how to increase and improve the visibility and transparency of the scientific achievements in ELD, as opposed to questioning the importance of 
international journals' rankings and fairness. Since Hungarian social scientists hardly appear regularly in Scopus, we can safely say that academic promotion according to HAS requirements does not depend on a high level of international visibility.

Our case study demonstrates the consequences of a country with a niche language, autocratic historical path, and relatively low level of research funding compared to mainstream scientific hubs choosing a locally driven publication science policy. Given the fact that HAS requirements for academic promotion rely on a special, domestic scientific repository, not on internationally recognized indexing systems, this results in the divergence between international visibility and academic promotion. Accordingly, Hungary might become isolated internationally in the social sciences, or find difficulty connecting to the mainstream discourses in these fields. Needless to say, this is not a conceptual problem if and when Hungarian social science serves its constituencies, which apparently are mainly local, or are not connected to competitive audits; for instance, international university ranking criteria, international research grant applications, or external financing sources.

\section{REFERENCES}

Astaneh, Behrooz-Sarah Masoumi (2018), „From Paper to Practice; Indexing Systems and Ethical Standards", Science and Engineering Ethics, 24(2), 647-654. Bacher, Johann - Knut Wenzig - Melanie Vogler (2004), SPSS Two Step ClusterA First Evaluation. Arbeits- und Diskussionspapiere: Sozialwissenschaftliches Institut Nürnberg. Nürnberg: Lehrstuhl für Soziologie.

Bastow Simon - Patrick Dunleavy - Jane Tinkler(2014), The Impact of Social Sciences: How Academics and Their Research Make a Difference. Los Angeles, London, New-Delhi, SIngapore: SAGE.

Bonitz M. - E. Bruckner - Andrea Scharnhorst (1997), „Characteristics and Impact of the Matthew Effect for Countries”, Scientometrics, 40(3), 407-422. Braun, Tibor (2010), „Új mutatószámok a tudományos folyóiratok értékelésére valóban indokolt-e az Impakt faktor egyeduralma?" (New Indicators For The Evaluation Of Journals), Magyar Tudomány (11), 215-220.

Bunz, Ulla (2006), „Publish or Perish: A Limited Author Analysis of ICA and NCA Journals", Journal of Communication, 55(4), 703-720. https:/doi. org/10.1111/j.1460-2466.2005.tb03018.x

Csaba, László - Szentes Tamás - Zalai Ernő (2014), „Tudományos-e a tudományosmérés? Megjegyzések a tudománymetria, az Impakt Faktor és az 
MTMT használatához" (Is scientific measurement scientific? Notes on Using Science Metrics, Impact Factor, and MTMT), Magyar Tudomány, 174(12), 442-466.

Delgado, Emilio - Rafael Repiso (2013), „The impact of scientific journals of communication: comparing Google Scholar Metrics", Web of Science and Scopus. Cominicar, 41(21), 45-52.

Demeter, Márton (2017a), „Author Productivity Index: Without Distortions”, Science and Engineering Ethics, 1-3. https://doi.org/10.1007/s11948-017-99547

Demeter, Márton (2017b), „The Core-Periphery Problem in Communication Research: A Network Analysis of Leading Publication", Publishing Research Quarterly, 33(4), 402-420.

Demeter, Márton (2018), „Nobody Notices It? Qualitative Inequalities of Leading Publication in Communication and Media Research", International Journal of Communication, 12, 1-18.

Gerke, Solvay - Hans-Dieter Evers (2006), „Globalizing Local Knowledge: Social Science Research on Southeast Asia 1970-2000", Journal of Social Issues in Southeast Asia, 21(1), 1-21.

González-Pereira, Borja - Vicente P.Guerrero-Bote - Félix Moya-Anegón (2010), „A new approach to the metric of journals' scientific prestige: The SJR indicator", Journal of Informetrics, 4(3), 379-391.

Gumpenberger, Christian - Johannes Sorz - Martin Wieland - Juan Gorraiz (2016), „Humanities and social sciences in the bibliometric spotlight Research output analysis at the University of Vienna and considerations for increasing visibility", Research Evaluation, 25(3), 271-278.

HAS Doctor of Science Requirements - www.mta.hu. (2018. 08 05). Az MTA IX. Gazdaság- és Jogtudományok Osztályának a doktori eljárásra vonatkozó követelményei: http://mta.hu/doktori-tanacs/a-ix-osztaly-doktorikovetelmenyrendszere-105380

Kornai, János (1992), The Socialist system: The political economy of Communism, Oxford: Oxford University Press.

Lauf, Edmund (2005), „National diversity of major international journals in the field of communication", Journal of Communication, 55(1), 139-151.

Makara, B. Gábor - Seres József (2013), „A Magyar Tudományos Mủvek Tára (MTMT) és az MTMT2" (The Repository of Hungarian Scientific Artefact (RHSA) database and RHSA2), Tudományos és müszaki tájékoztatás, 60(4), 191-195.

Nederhof, Anton J. (2006), „Bibliometric monitoring of research performance in the Social Sciences and the Humanities: A review", Scientometrics, 1, 81100. 
Pajić, Dejan (2015), „Globalization of the social sciences in Eastern Europe: genuine breakthrough or a slippery slope of the research evaluation practice?", Scientometrics, 102: 2131-2150. https://doi.org/10.1007/s11192-014-1510-5

Sasvári, Péter - Nemeslaki András - Duma László (2019), „Exploring the influence of scientific journal ranking on publication performance in the Hungarian social sciences: the case of law and economics", Scientometrics 119: 595-616. doi: https://doi.org/10.1007/s11192-019-03081-4

Schmoch, Ulrich - Torben Schubert (2008), „Are International co-publications an indicator for quality of scientific research?", Scientometrics, 74(3), 361-377. Shenhav, Yehouda A. (1986), „Dependency and compliance in academic research infrastructures", Sociological Perspectives, 28(1), 29-51.

Soós, Sándor - Schubert András (2014), PTB-folyóiratlista MTMT-alapú osztályozása kutatásértékelési eljárásokhoz (RHSA-based classification of PTB journal list for research evaluation procedures), Budapest, http://www. mtakszi.iif.hu/docs/jelentesek/TTO_jelentes_MTMT2_D6.pdf

Templeton, Gary F. - Bruce R. Lewis (2015), „Fairness in the Institutional Valuation of Business Journals", MIS Quarterly, 39(3), 523-539.

Teodorescu, Daniel - Tudorel Andrei (2011), „The growth of international collaboration in East European scholarly communities: a bibliometric analysisof journal articles published between 1989 and 2009", Scientometrics, 89(2), 711-722.

Tolnai, Márton - Mosoniné Fried Judit - Soós Sándor (2009), „Fiatal Kutatók az MTA Köztestületében" (Young researchers in the Hungarian Academy of Sciences), Magyar Tudomány, 170(3), 334-344.

Trpkova, Marija - Dragan Tevdovski (2010), „Twostep cluster analysis: Segmentation of largest companies in Macedonia", In Kovács, Péter - Szép Katalin - Katona Tamás eds., Challenges for Analysis of the Economy, the Businesses, and Social Progress, 302-320. Szeged, Hungary: Unidocument Kft.

Vinkler, Péter (2008), "Correlation between the structure of scientific research, scientometric icdicators and GDP in EU and non-EU countries", Scientometrics, 74(2), 237-254.

Wang, Lili - Xianwen Wang (2017), „Who sets up the bridge? Tracking scientific collaborations between China and the European Union", Research Evaluation, 26(2), 124-131.

Wiedemann, Thomas - Meyen Michael (2016), „Internationalization Through Americanization: The Expansion of the International Communication Association's Leadership to the World", International Journal of Communication, 10, 1489-1509. 